\title{
Nutritional Evaluation of Millet Plants Grown in Soils Fertilized With Organic Wastes From Different Sources
}

\author{
Wilker A. Morais ${ }^{1}$, Frederico A. L. Soares ${ }^{1}$, Fernando N. Cunha ${ }^{1}$, Marconi B. Teixeira ${ }^{1}$, Cicero T. S. Costa ${ }^{1}$, \\ Fernando R. Cabral Filho ${ }^{1}$, Gustavo da S. Vieira ${ }^{1}$, Vitória R. de C. Martins ${ }^{1}$, Vinícius de O. Marques ${ }^{1}$, \\ Giovani S. Moraes ${ }^{1}$, Aurélio F. Melo ${ }^{1}$, Igor O. F. Silva ${ }^{1} \&$ Leandro S. Pereira ${ }^{1}$ \\ ${ }^{1}$ Center of Agricultural Sciences, Federal Institute of Goiás, Campus Rio Verde, Goiás, Brazil \\ Correspondence: Fernando N. Cunha, Center of Agricultural Sciences, Instituto Federal Goiano, Campus Rio \\ Verde, Goiás, Brazil. Tel: 55-643-620-5600. E-mail: fernandonobrecunha@hotmail.com
}

Received: November 18, 2018

doi:10.5539/jas.v11n4p325
Accepted: January 24, 2019 Online Published: March 15, 2019

URL: https://doi.org/10.5539/jas.v11n4p325

\begin{abstract}
The losses of essential elements to crops make necessary to correct soil fertility to meet the nutritional requirements of plants, which can be achieved by increasing soil organic matter. The objective of this work was to evaluate the leaf nutritional conditions of millet plants grown in soils fertilized with organic wastes from different sources at different rates. Organic matter can make the soil more productive and suitable to agricultural crops. A randomized block experimental design with a $4 \times 2$ factorial arrangement was used with four replications, consisting of 32 experimental units. The treatments consisted of four organic matter sources (swine manure, sewage sludge, bovine manure, and poultry litter), and two organic matter rates $(20 \%$ and $40 \%$ of the pot volume). Boron extraction was performed by dry digestion - the organic matter of the plant tissue was incinerated in an electric muffle furnace at $450-550{ }^{\circ} \mathrm{C}$, and the inorganic residue (ash) was dissolved in a dilute acid solution. $\mathrm{N}, \mathrm{K}, \mathrm{Ca}, \mathrm{Mg}, \mathrm{S}, \mathrm{Fe}, \mathrm{Cu}, \mathrm{Mn}$, and $\mathrm{Zn}$ was extracted through wet digestion - the organic matter of the leaf tissue was oxidized by concentrated mineral acids and by heat. N, P, S, B, Ca, Mg, Cu, Fe, Mn, and Zn was determined by spectrophotometry. $\mathrm{K}$ was determined by flame photometry. All macro and micronutrient contents in the millet leaves, and biometric parameters of the millet panicle were affected by the organic matter sources, organic matter rates, and the interaction between them.
\end{abstract}

Keywords: Pennisetum glaucum, swine manure; sewage sludge

\section{Introduction}

The use of lands for agricultural purposes contributes to soil nutrient loss due to crop harvest (Galvão et al., 2008; Santos et al., 2010). Moreover, nutrients are lost through volatilization, inadequate fertilization, and fertilizer runoff (Novais et al., 2007). The losses of essential elements to crops make necessary to correct soil fertility to meet the nutritional requirements of plants, agricultural crops, and native species for recovery of degraded areas, which can be achieved by increasing soil organic matter, since organic matter is a great soil conditioner that generates physical, chemical, and biological improvements (Alcântara \& Madeira, 2008).

Organic matter can make the soil more productive and suitable to agricultural crops. The most used organic fertilizers for supplying organic matter to soils are bovine manure, chicken litter, swine manure, and more recently, sewage sludge (Morais, 2016).

Bovine manure and poultry litter are low moisture residues and are, therefore, known as solid wastes. However, wastes may vary in concentration of nutrients depending on the dilution, handling, and storing (Oliveira, 1993). Effluent or sewage sludge are residues with plenty moisture. All residues must undergo a previous treatment of composting before incorporated into the soil to avoid damage to crops by phytotoxicity. Organic fertilization is important for agriculture, especially for millet crops.

Millet is an important annual crop for animal feed; this crop can replace maize and other grains. This species does not present dhurrin, which is found in sorghum plants, thus, it is not toxic to animals at any vegetative stage, and can be used as grazing, hay, silage, and grain feed (Fontaneli et al., 2012). The objective of this work was to evaluate the leaf nutritional conditions of millet plants grown in soils fertilized with organic wastes from different sources at different rates. 


\section{Materials and Methods}

The experiment was conducted in a greenhouse at the Federal Institute of Goiás, Rio Verde campus, southwest of the state of Goiás, Brazil $\left(17^{\circ} 47^{\prime} 53^{\prime \prime} \mathrm{N}, 51^{\circ} 55^{\prime} 53^{\prime \prime} \mathrm{S}\right.$, and altitude of $\left.743 \mathrm{~m}\right)$. The soil was characterized as Dystroferric Red Latossolo (Oxisol) (Embrapa, 2013).

A randomized block experimental design with a $4 \times 2$ factorial arrangement was used with four replications, consisting of 32 experimental units. The treatments consisted of four organic matter sources (swine manure, sewage sludge, bovine manure, and poultry litter), and two organic matter rates $(20 \%$ and $40 \%$ of the pot volume).

Fifty-liter pots filled with an agricultural soil that is predominant in the region were used. The pots were filled with $80 \%$ of soil and $20 \%$ of organic matter; and with $60 \%$ of soil and $40 \%$ of organic matter. The soil chemical analysis after the treatments is shown in Table 1. The soil analysis was performed according to Silva et al. (2009).

Table 1. Analysis of macronutrients and micronutrients of soils treated with organic wastes and used for the planting of millet

\begin{tabular}{|c|c|c|c|c|c|c|c|c|}
\hline \multirow{2}{*}{ Treatments } & \multicolumn{7}{|c|}{ Macronutrients $^{1}$} & \multirow{2}{*}{$\mathrm{pH}$} \\
\hline & $\mathrm{Ca}$ & $\mathrm{Mg}$ & $\mathrm{Al}$ & $\mathrm{K}$ & $\mathrm{K}$ & $\mathrm{S}$ & $\mathrm{P}(\mathrm{mol})$ & \\
\hline & \multicolumn{4}{|c|}{--------------- $\mathrm{cmol}_{\mathrm{c}} \mathrm{dm}^{-3}$--------------- } & \multicolumn{3}{|c|}{------------- $\mathrm{mg} \mathrm{dm}^{-3}$----------. } & \\
\hline SM $20 \%$ & 4.44 & 1.14 & 0.00 & 0.32 & 126.0 & 114.9 & 33.40 & 6.2 \\
\hline $\mathrm{SM} 40 \%$ & 4.43 & 1.15 & 0.01 & 0.34 & 133.0 & 116.8 & 23.35 & 5.5 \\
\hline SS $20 \%$ & 3.20 & 0.94 & 0.05 & 0.32 & 126.0 & 101.2 & 21.85 & 4.9 \\
\hline SS $40 \%$ & 3.28 & 0.83 & 0.10 & 0.30 & 119.0 & 161.3 & 20.79 & 4.7 \\
\hline BM $20 \%$ & 2.33 & 1.18 & 0.00 & 0.91 & 356.0 & 12.5 & 28.39 & 7.1 \\
\hline $\mathrm{BM} 40 \%$ & 3.76 & 2.35 & 0.00 & 1.67 & 652.0 & 20.1 & 87.70 & 7.3 \\
\hline PL 20\% & 1.92 & 2.06 & 0.00 & 0.00 & 1.3 & 72.1 & 154.49 & 8.1 \\
\hline PL $40 \%$ & 1.44 & 3.06 & 0.00 & 0.01 & 2.4 & 181.1 & 263.09 & 8.3 \\
\hline \multirow{2}{*}{ Treatments } & \multicolumn{6}{|c|}{ Micronutrients } & \multirow{2}{*}{$\mathrm{OM}$} & \multirow{2}{*}{ CEC } \\
\hline & $\mathrm{Na}$ & $\mathrm{Fe}$ & $\mathrm{Mn}$ & $\mathrm{Cu}$ & $\mathrm{Zn}$ & $\mathrm{B}$ & & \\
\hline & \multicolumn{6}{|c|}{ - } & $\mathrm{g} \mathrm{dm}^{-3}$ & $\mathrm{cmol}_{\mathrm{c}} \mathrm{dm}^{-3}$ \\
\hline SM $20 \%$ & 19.00 & 13.85 & 53.74 & 5.59 & 19.54 & 0.16 & 35.7 & 7.69 \\
\hline SM $40 \%$ & 18.00 & 12.07 & 54.41 & 2.20 & 10.33 & 0.28 & 39.6 & 8.32 \\
\hline SS $20 \%$ & 37.00 & 69.91 & 96.20 & 5.09 & 18.16 & 0.29 & 34.1 & 8.04 \\
\hline SS $40 \%$ & 45.00 & 90.36 & 118.05 & 3.26 & 21.01 & 0.23 & 39.0 & 8.10 \\
\hline BM $20 \%$ & 33.00 & 12.39 & 47.70 & 3.04 & 5.75 & 0.18 & 30.3 & 5.59 \\
\hline $\mathrm{BM} 40 \%$ & 55.00 & 15.05 & 110.07 & 3.09 & 11.27 & 0.31 & 49.8 & 9.01 \\
\hline PL 20\% & 360.00 & 12.10 & 111.89 & 8.17 & 10.78 & 1.94 & 31.0 & 6.25 \\
\hline PL $40 \%$ & 240.00 & 8.66 & 127.61 & 5.60 & 14.40 & 2.49 & 51.3 & 6.21 \\
\hline
\end{tabular}

Note. ${ }^{1}$ Macronutrients and Micronutrients. Treatments: swine manure (SM); sewage sludge (SS); bovine manure $(\mathrm{BM})$; poultry litter $(\mathrm{PL})$; organic matter $(\mathrm{OM})$; cation exchange capacity (CEC).

Millet seeds of the cultivar BRS 1501 (Brazilian Agricultural Research Company Embrapa) were sown in April 2016. Chemical analysis of the millet leaves was performed to determine the nutritional status of the plants at 80 days after sowing (DAS).

Green leaves were washed with tap water and later with distilled water, dried in a forced-air circulation oven at $60^{\circ} \mathrm{C}$ to a constant weight, crushed in a Wiley mill and passed through a $1.0-\mathrm{mm}$ mesh sieve.

Boron extraction was performed by dry digestion - the organic matter of the plant tissue was incinerated in an electric muffle furnace at $450-550{ }^{\circ} \mathrm{C}$, and the inorganic residue (ash) was dissolved in a dilute acid solution. $\mathrm{N}$, $\mathrm{K}, \mathrm{Ca}, \mathrm{Mg}, \mathrm{S}, \mathrm{Fe}, \mathrm{Cu}, \mathrm{Mn}$, and $\mathrm{Zn}$ was extracted through wet digestion — the organic matter of the leaf tissue was oxidized by concentrated mineral acids and by heat.

$\mathrm{N}, \mathrm{P}, \mathrm{S}, \mathrm{B}, \mathrm{Ca}, \mathrm{Mg}, \mathrm{Cu}, \mathrm{Fe}, \mathrm{Mn}$, and $\mathrm{Zn}$ was determined by spectrophotometry. $\mathrm{K}$ was determined by flame photometry. The chemical analysis of the plant tissue was performed according to the methodology described by Miyazawa et al. (2009). 
The data of each variable were subjected to analysis of variance using the SISVAR program (Ferreira, 2011). Significant means by the $\mathrm{F}$ test were subjected to the Tukey's test at $5 \%$ probability for the organic matter sources and rates.

\section{Results and Discussion}

Leaf macronutrients and micronutrients are important to evaluate the nutritional status of the plant. The interaction between the organic matter sources (OMS) and rates (OMR), and the isolated effects of OMS and OMR were significant for all macronutrient contents (N, P, K, Ca, Mg, and S) (Table 2), except the effect of OMR on $\mathrm{N}$ and $\mathrm{K}$.

Table 2. ANAVA to evaluate the significance of the sources of variation of macronutrient contents in millet leaves

\begin{tabular}{llllllll}
\hline \multirow{2}{*}{ SV } & DF & \multicolumn{7}{c}{ Mean square $^{1}$} \\
\cline { 3 - 7 } & & $\mathrm{N}$ & $\mathrm{P}$ & $\mathrm{K}$ & $\mathrm{Ca}$ & $\mathrm{Mg}$ & $\mathrm{S}$ \\
\hline OMS & 3 & $122.95^{* *}$ & $2.23^{* *}$ & $325.30^{* *}$ & $48.71^{* *}$ & $2.35^{* *}$ & $0.10^{* *}$ \\
OMR & 1 & $2.26^{\text {ns }}$ & $1.62^{* *}$ & $0.17^{\text {ns }}$ & $33.62^{* *}$ & $8.00^{* *}$ & $0.25^{* *}$ \\
OMS $\times$ OMR & 3 & $64.33^{* *}$ & $0.67^{* *}$ & $13.94^{* *}$ & $6.42^{* *}$ & $1.37^{* *}$ & $0.05^{* *}$ \\
Block & 3 & $21.73^{* *}$ & $0.27^{* *}$ & $4.63^{* *}$ & $0.70^{* *}$ & $0.21^{* *}$ & $0.04^{* *}$ \\
Residual & 21 & 0.71 & 0.009 & 0.26 & 0.03 & 0.01 & 0.002 \\
CV (\%) & & 1.85 & 1.60 & 1.21 & 2.17 & 2.53 & 1.64 \\
\hline
\end{tabular}

Note. ${ }^{1}$ Source of variation (SV); degree of freedom (DF); organic matter source (OMS); organic matter rate (OMR); coefficient of variation $(\mathrm{CV}){ }^{*}{ }^{*}$ significant at $5 \%$ by the $\mathrm{F}$ test; ${ }^{* *}$ significant at $1 \%$ by the $\mathrm{F}$ test and ${ }^{\mathrm{ns}}$ not significant at $5 \%$ by the $\mathrm{F}$ test.

Usually, the interactions between soil characteristics and nutrient elements contribute negatively to the available level of nutrients in millet, however, organic matter in the soil is related positively to an increase of nutrient availability favoring to grains yield and quality (Tisdale et al., 1993; Koukoulakis et al., 2000, 2013).

The OMR was not significant for $\mathrm{N}$ only for swine manure (SM) (Table 3). Plants in soils with poultry litter (PL), and bovine manure (BM) had higher leaf $\mathrm{N}$ contents than those in soils with sewage sludge (SS), when applying OMR of $40 \%$. Plants in soils with the OMR of $20 \%$ had the highest leaf $\mathrm{N}$ contents in the treatments with PL, $\mathrm{SM}$, and BM. The plants in soils with the OMR of $40 \%$ had the highest leaf $\mathrm{N}$ contents in the treatments with SS, and the lowest in the treatments with SM. Younger leaves contain more $\mathrm{N}$ than elder due to the effective $\mathrm{N}$ uptake of young leaves, consequently, the changing of $\mathrm{N}$ content of leaves is more remarkable in the initial phase, what requires the fast availability of this nutrient (Nagy \& Holb, 2006). 
Table 3. Significance of the interaction between organic matter sources (OMS) and organic matter rates (OMR) for macronutrients in millet leaves

\begin{tabular}{|c|c|c|c|c|}
\hline \multirow{2}{*}{ OMR (\%) } & \multicolumn{4}{|c|}{$\mathrm{OMS}^{1}$} \\
\hline & PL & SM & BM & SS \\
\hline \multicolumn{5}{|l|}{$N\left(g \mathrm{~kg}^{-1}\right)$} \\
\hline 20 & $49.6 \mathrm{aA}$ & $40.13 \mathrm{aC}$ & $46.80 \mathrm{aB}$ & $46.80 \mathrm{bB}$ \\
\hline 40 & $42.9 \mathrm{bB}$ & $41.00 \mathrm{aC}$ & $43.90 \mathrm{bB}$ & $53.40 \mathrm{aA}$ \\
\hline \multicolumn{5}{|l|}{$P\left(g k^{-1}\right)$} \\
\hline 20 & $6.30 \mathrm{aB}$ & $6.50 \mathrm{aA}$ & $5.70 \mathrm{aC}$ & $6.20 \mathrm{aB}$ \\
\hline 40 & $6.40 \mathrm{aA}$ & $6.40 \mathrm{aA}$ & $5.10 \mathrm{bB}$ & $5.00 \mathrm{bB}$ \\
\hline \multicolumn{5}{|l|}{$K\left(\mathrm{~kg}^{-1}\right)$} \\
\hline 20 & $45.00 \mathrm{bB}$ & $42.50 \mathrm{aC}$ & $46.53 \mathrm{bA}$ & $34.50 \mathrm{aD}$ \\
\hline 40 & $48.00 \mathrm{aA}$ & $40.30 \mathrm{bB}$ & $48.30 \mathrm{aA}$ & $32.50 \mathrm{bC}$ \\
\hline \multicolumn{5}{|l|}{$\mathrm{Ca}\left(g \mathrm{~kg}^{-1}\right)$} \\
\hline 20 & $5.70 \mathrm{aD}$ & $10.00 \mathrm{aB}$ & $8.90 \mathrm{aC}$ & $10.60 \mathrm{aA}$ \\
\hline 40 & $2.90 \mathrm{bD}$ & $10.20 \mathrm{aA}$ & $7.30 \mathrm{bB}$ & $6.60 \mathrm{bC}$ \\
\hline \multicolumn{5}{|l|}{$M g\left(g \mathrm{~kg}^{-1}\right)$} \\
\hline 20 & $3.80 \mathrm{aA}$ & $5.10 \mathrm{aB}$ & $4.90 \mathrm{aB}$ & $5.10 \mathrm{aB}$ \\
\hline 40 & $3.40 \mathrm{bC}$ & $4.60 \mathrm{bA}$ & $4.00 \mathrm{bB}$ & $2.90 \mathrm{bD}$ \\
\hline \multicolumn{5}{|l|}{$S\left(g \mathrm{~kg}^{-1}\right)$} \\
\hline 20 & 3.30aAB & $3.20 \mathrm{aB}$ & $3.20 \mathrm{aB}$ & $3.40 \mathrm{aA}$ \\
\hline 40 & $3.30 \mathrm{aA}$ & $2.90 \mathrm{bC}$ & $3.10 \mathrm{bB}$ & $3.10 \mathrm{bB}$ \\
\hline
\end{tabular}

Note. ${ }^{1}$ Means followed by the same lowercase letter in the columns and uppercase letter in the rows do not differ by the Tukey's test at $5 \%$ probability. Organic matter source (OMS); organic matter rate (OMR); poultry litter (PL); swine manure (SM); bovine manure (BM); sewage sludge (SS); $20=20 \%$ of organic matter; $40=40 \%$ of organic matter.

The OMR affected the P contents of plants in soils with BM and SS; and the plants had the highest P contents when using the OMR of $20 \%$. The highest P contents with the OMR of $20 \%$ were found in plants in soils with $\mathrm{SM}$, and the lowest in plants in soils with BM; and the highest P contents with the OMR of $40 \%$ were found in plants in soils with PL, and SM (Table 3). According to Sobrado (2014) the N and P are co-limiting macronutrients in the crops that growing in oxisol soil.

The OMR affected the leaf $\mathrm{K}$ contents of plants, regardless the OMS used (Table 3). The highest leaf $\mathrm{K}$ contents were found in plants in soils with SM, and SS. The highest K contents with the OMR of $20 \%$ were found plants in soils with BM, and the lowest with SM. The highest K contents with the OMR of $40 \%$ were found in plants in soils with PL, and BM, and the lowest with SS. Bouhafa et al. (2018) observed very highly significant differences were found between the leaf $\mathrm{N}$ and $\mathrm{K}$ levels measured at different sampling periods, indicating the high $\mathrm{N}$ and $\mathrm{K}$ needs of crops.

The OMR affected the leaf Ca contents of plants in soils with PL, BM, and SS (Table 3). The highest Ca in the leaves were found with the OMR of $20 \%$. The highest leaf $\mathrm{Ca}$ contents with the OMR of $20 \%$ were found in plants in soils with SS, and the lowest with PL. The highest leaf Ca contents with the OMR of $40 \%$ were found in plants in soils with SM, and the lowest with PL. Miljković and Vrsaljko (2009) noted that the leaf had higher $\mathrm{N}$ and $\mathrm{K}$, and lower $\mathrm{Ca}$ levels.

The OMR affected the leaf Mg contents, regardless the OMS used. Plants in soils with the OMR of $20 \%$ had higher Mg contents than those in soils with $40 \%$. The highest Mg contents with the OMR of $20 \%$ were found in plants in soils with PL. The highest Mg contents with the OMR of $40 \%$ were found in plants in soils with SM, and the lowest with SS. The status that leaf $\mathrm{Mg}$ is in excessive range when leaf $\mathrm{K}$ is in deficiency due to a consequence of lower K competition (Nachtigall \& Dechen, 2006; T. Milošević \& N. Milošević, 2015), however, in this study were observed lower Mg levels.

The OMR only affect the leaf S contents of plants in soils with PL. Plants in soils with SM, BM, and SS had the highest leaf S contents at OMR of $20 \%$. The highest S contents with the OMR of $20 \%$ were found in plants in 
soils with SS. The highest S contents with the OMR of $40 \%$ were found in plants in soils with PL, and the lowest with SM.

Araújo et al. (2008) evaluated the effects of natural and composted tannery sludges combined with phosphate on maize production components, soil fertility, and chromium accumulation in the soil and found higher $\mathrm{N}, \mathrm{P}, \mathrm{K}, \mathrm{Ca}$, $\mathrm{Mg}$, and $\mathrm{S}$ contents for treatments containing sewage sludge. The highest contents of these elements with the OMR of $20 \%$ were found, in general, in plants in soils with SS, and PL. The highest macronutrient contents with the OMR of $40 \%$ were found, in general, in plants in soils with PL, and SM.

The highest $\mathrm{N}$ content $\left(53.40 \mathrm{~g} \mathrm{~kg}^{-1}\right)$ were found when using SS at OMR of $40 \%$, and the lowest $\left(40.13 \mathrm{~g} \mathrm{~kg}^{-1}\right)$ when using SM at OMR of $20 \%$. The soil with SM at OMR of $20 \%$ had the highest P content $\left(6.50 \mathrm{~g} \mathrm{~kg}^{-1}\right)$, and that with SS at OMR of $40 \%$ had the lowest P content $\left(5.00 \mathrm{~g} \mathrm{~kg}^{-1}\right)$. The soil P contents when using SM at OMR of $20 \%$, and SS at OMR of $40 \%$ were 33.40 , and $20.79 \mathrm{mg} \mathrm{dm}^{-3}$, respectively.

The highest K content $\left(48.30 \mathrm{~g} \mathrm{~kg}^{-1}\right)$ was found when using BM at OMR of $40 \%$, and the lowest $\left(32.50 \mathrm{~g} \mathrm{~kg}^{-1}\right)$ when using SS at OMR of $40 \%$. The soil $\mathrm{K}$ contents when using BM at OMR of $40 \%$, and SS at OMR of $40 \%$ were 652.0 , and $119.0 \mathrm{mg} \mathrm{dm}^{-3}$, respectively.

According to Pitta et al. (2012) the nutrient release rate was highest during the first 60 days of decomposition and after 150 days of litter incubation in the field, 54, 51, 100, and $52 \%$ of N, P, K and Ca had become available to the soil, and also reported the residual effects of and nutrient release from organic matter source decomposition can last longer than a year.

The highest Ca content $\left(10.60 \mathrm{~g} \mathrm{~kg}^{-1}\right)$ was found when using SS at OMR of $20 \%$, and the lowest $\left(2.90 \mathrm{~g} \mathrm{~kg}^{-1}\right)$ when using PL at OMR of $40 \%$. The soil Ca contents when using SS at OMR of $20 \%$, and PL at OMR of $40 \%$ were 3.20 , and $1.44 \mathrm{cmol}_{\mathrm{c}} \mathrm{dm}^{-3}$, respectively. Calcium concentration increases with age as a high proportion in the plant tissue is located in the cell walls (Marschner, 1995). The highest Mg content $\left(5.10 \mathrm{~g} \mathrm{~kg}^{-1}\right)$ was found when using SM, and SS at OMR of $20 \%$, and the lowest $\left(2.90 \mathrm{~g} \mathrm{~kg}^{-1}\right)$ when using SS at OMR of $40 \%$. The soil $\mathrm{Mg}$ contents when using SM, and SS at OMR of $20 \%$, and SS at OMR of $40 \%$ were $1.14,0.94$, and $0.83 \mathrm{cmol}_{\mathrm{c}}$ $\mathrm{dm}^{-3}$, respectively.

The highest S content $\left(3.40 \mathrm{~g} \mathrm{~kg}^{-1}\right)$ were found when using SS at OMR of $20 \%$, and the lowest $\left(2.90 \mathrm{~g} \mathrm{~kg}^{-1}\right)$ when using SM at OMR of $40 \%$ (Table 3). The soil S contents when using SS at OMR of $20 \%$, and SM at OMR of $40 \%$ were 101.2 , and $116.8 \mathrm{mg} \mathrm{dm}^{-3}$, respectively.

The isolated effects of OMS and OMR, and their interaction were significant for the micronutrients $\mathrm{Fe}, \mathrm{Mn}, \mathrm{Cu}$, $\mathrm{Zn}$, and B (Table 4).

Table 4. ANAVA to evaluate the significance of the sources of variation of micronutrient contents in millet leaves

\begin{tabular}{|c|c|c|c|c|c|c|}
\hline \multirow{2}{*}{ SV } & \multirow{2}{*}{ DF } & \multicolumn{5}{|c|}{ Mean square $^{1}$} \\
\hline & & $\mathrm{Fe}$ & $\mathrm{Mn}$ & $\mathrm{Cu}$ & $\mathrm{Zn}$ & B \\
\hline OMS & 3 & $111356.87^{* *}$ & $198755.01^{* *}$ & $128.05^{* *}$ & $5739.03^{* *}$ & $1438.21^{* *}$ \\
\hline PMO & 1 & $18542.57^{* *}$ & $26450.00^{* *}$ & $16.68^{* *}$ & $378.13^{* *}$ & $19.22^{* *}$ \\
\hline $\mathrm{OMS} \times \mathrm{OMR}$ & 3 & $34237.16^{* *}$ & $26537.76^{* *}$ & $88.18^{* *}$ & $1289.58^{* *}$ & $42.31^{* *}$ \\
\hline Block & 3 & $3673.25^{* *}$ & $896.14^{* *}$ & $6.68^{* *}$ & $25.23^{* *}$ & $4.94^{* *}$ \\
\hline Residual & 21 & 86.86 & 8.97 & 0.24 & 1.83 & 0.14 \\
\hline $\mathrm{CV}(\%)$ & & 2.10 & 1.35 & 2.47 & 2.17 & 1.90 \\
\hline
\end{tabular}

Note. ${ }^{1}$ Source of variation (SV); degree of freedom (DF); organic matter source (OMS); organic matter rate $(\mathrm{OMR})$; coefficient of variation $(\mathrm{CV}) ;{ }^{*}$ significant at $5 \%$ by the $\mathrm{F}$ test; ${ }^{* *}$ significant at $1 \%$ by the $\mathrm{F}$ test and ${ }^{\mathrm{ns}}$ not significant at $5 \%$ by the $\mathrm{F}$ test.

The OMR affected the leaf Fe contents of plants, regardless the OMS used; plants in soils with the OMR of 20\% had higher Fe contents when using PL, and BM, when compared to the OMR of $40 \%$ (Table 5). The highest Fe contents with the OMR of $20 \%$ were found in plants in soils with BM, and the lowest with PL. The highest Fe contents with the OMR of $40 \%$ were found in plants in soils with SM, and the lowest with PL. 
Table 5. Significance of the interaction between organic matter sources (OMS) and organic matter rates (OMR) for micronutrients in millet leaves

\begin{tabular}{|c|c|c|c|c|}
\hline \multirow{2}{*}{ OMR (\%) } & \multicolumn{4}{|c|}{ OMS } \\
\hline & PL & SM & $\mathrm{BM}$ & $\mathrm{SS}$ \\
\hline \multicolumn{5}{|c|}{$\mathrm{Fe}\left(\mathrm{mg} \mathrm{kg^{-1 }}\right)$} \\
\hline 20 & $314.63 \mathrm{aD}$ & $368.80 \mathrm{bC}$ & $543.93 \mathrm{aA}$ & $454.33 \mathrm{bB}$ \\
\hline 40 & $227.83 b D$ & $576.20 \mathrm{aA}$ & $518.73 \mathrm{bC}$ & $551.50 \mathrm{aB}$ \\
\hline \multicolumn{5}{|c|}{$\operatorname{Mn}\left(m g k^{-1}\right)$} \\
\hline 20 & $311.80 \mathrm{aB}$ & $98.70 \mathrm{bD}$ & $109.80 \mathrm{aC}$ & $483.50 \mathrm{aA}$ \\
\hline 40 & $108.10 \mathrm{bC}$ & $173.20 \mathrm{aB}$ & $80.70 \mathrm{bD}$ & $411.80 \mathrm{bA}$ \\
\hline \multicolumn{5}{|c|}{$\mathrm{Cu}\left(\mathrm{mg} \mathrm{kg}^{-1}\right)$} \\
\hline 20 & $31.20 \mathrm{aA}$ & $14.70 \mathrm{bD}$ & $17.40 \mathrm{bC}$ & $20.00 \mathrm{bB}$ \\
\hline 40 & $20.03 \mathrm{bA}$ & $18.50 \mathrm{aB}$ & $18.20 \mathrm{aB}$ & $20.80 \mathrm{aA}$ \\
\hline \multicolumn{5}{|c|}{$\mathrm{Zn}\left(\mathrm{mg} \mathrm{kg}^{-1}\right)$} \\
\hline 20 & $63.90 \mathrm{aC}$ & $67.40 \mathrm{aB}$ & $27.20 \mathrm{bD}$ & $77.40 \mathrm{bA}$ \\
\hline 40 & $53.40 \mathrm{bB}$ & $53.10 \mathrm{bB}$ & $38.50 \mathrm{aC}$ & $118.40 \mathrm{aA}$ \\
\hline \multicolumn{5}{|l|}{$B\left(m g g^{-1}\right)$} \\
\hline 20 & $42.80 \mathrm{aA}$ & $10.50 \mathrm{bD}$ & $12.50 \mathrm{aC}$ & $12.50 \mathrm{bB}$ \\
\hline 40 & $37.00 \mathrm{bA}$ & $15.10 \mathrm{aB}$ & $11.70 \mathrm{bD}$ & $16.70 \mathrm{aC}$ \\
\hline
\end{tabular}

Note. ${ }^{1}$ Means followed by the same lowercase letter in the columns and uppercase letter in the rows do not differ by the Tukey's test at 5\% probability. Organic matter source (OMS); organic matter rate (OMR); poultry litter (PL); swine manure (SM); bovine manure (BM); sewage sludge (SS); $20=20 \%$ of organic matter; $40=40 \%$ of organic matter.

The results for the effect of OMR on Mn contents were similar to those found for Fe, in all OMS (Table 5). Plants in soils with SS had the highest Mn contents, regardless the OMR used, and plants in soils with SM at OMR of $20 \%$, and BM at OMR of $40 \%$ had the lowest.

The OMR affected $\mathrm{Cu}$ contents of plants, regardless the OMS used. Only the plants in soil with PL had the highest leaf $\mathrm{Cu}$ contents with the OMR of $20 \%$. The highest leaf $\mathrm{Cu}$ contents with the OMR of $20 \%$ was found in plants in soils with PL, and the lowest with SM. The highest leaf $\mathrm{Cu}$ contents with the OMR of $40 \%$ was found in plants in soils with PL, and SS, and the lowest with SM, and BM.

The OMR affected the leaf Zn contents of plants, regardless the OMS used. The highest Zn contents were found in plants in soils with PL, and SM at OMR of 20\%. The highest Zn contents with the OMR of $20 \%$ and $40 \%$ were found in plants in soils with SS, and the lowest with BM.

The OMR affected the leaf B contents of plants, regardless the OMS used. The highest B contents were found in plants in soils with PL, and BM at OMR of 20\% (Table 5). The highest B contents with the OMR of $20 \%$ and $40 \%$ were found in plants in soils with PL, and the lowest with SM (20\%), and BM (40\%).

Teixeira et al. (2008) evaluated content and accumulation of micronutrients in millet, jack bean, pigeon pea, and gramineous intercropped with legumes, and found the following results for millet plants: Fe $\left(643.97 \mathrm{mg} \mathrm{kg}^{-1}\right)$, Mn (101.93 mg kg$\left.{ }^{-1}\right), \mathrm{Cu}\left(9.80 \mathrm{mg} \mathrm{kg}^{-1}\right), \mathrm{Zn}\left(98.13 \mathrm{mg} \mathrm{kg}^{-1}\right)$ and B $\left(11.70 \mathrm{mg} \mathrm{kg}^{-1}\right)$. The highest Fe contents in the present work $\left(576 \mathrm{mg} \mathrm{kg}^{-1}\right)$ was found for SM at OMR of 40\%, and the lowest $\left(227.83 \mathrm{mg} \mathrm{kg}^{-1}\right)$ for PL at OMR of $40 \%$ (Table 5). These Fe contents were lower than those found by Teixeira et al. (2008). The soil Fe contents with SM at OMR of 40\%, and PL at OMR of $40 \%$ were 12.07 , and $8.66 \mathrm{mg} \mathrm{dm}^{-3}$, respectively.

The highest Mn contents (483 $\left.\mathrm{mg} \mathrm{kg}^{-1}\right)$ was found when using SS at OMR of $20 \%$, and the lowest $\left(80.70 \mathrm{mg} \mathrm{kg}^{-1}\right)$ when using BM at OMR of $40 \%$. The highest Mn contents found were well above those found by Teixeira et al. (2008). The soil Mn contents when using SS at OMR of 20\%, and BM at OMR of 40\% were 96.20, and 110.07 $\mathrm{mg} \mathrm{dm}$, respectively. The highest $\mathrm{Cu}$ contents $\left(31.20 \mathrm{mg} \mathrm{kg}^{-1}\right)$ were found in plants in soils with PL at OMR of $20 \%$ and the lowest $\left(14.70 \mathrm{mg} \mathrm{kg}^{-1}\right)$ with SM at OMR of $20 \%$. These results were above those found by Teixeira et al. (2008). The soil $\mathrm{Cu}$ contents when using PL at OMR of 20\%, and SM at OMR of 20\% were 8.17, and 5.59 $\mathrm{mg} \mathrm{dm}{ }^{-3}$, respectively. 
The highest $\mathrm{Zn}$ content (118.40 $\left.\mathrm{mg} \mathrm{kg}^{-1}\right)$ was found when using SS at OMR of 40\%, and the lowest (27.20 mg $\mathrm{kg}^{-1}$ ) when using BM at $20 \%$ (Table 5). The lowest $\mathrm{Zn}$ found is well below that found by Teixeira et al. (2008). The soil $\mathrm{Zn}$ contents when using SS at OMR of 40\%, and BM at OMR of 20\% were 21.01, and $5.75 \mathrm{mg} \mathrm{dm}^{-3}$, respectively. The highest B content (42.80 mg kg $\mathrm{g}^{-1}$ ) was found when using PL at OMR of $20 \%$, and the lowest (11.70 mg kg-1) when using BM at OMR of 40\% (Table 5). The lowest B content was similar to that found by Teixeira et al. (2008). The soil B contents when using PL at OMR of 20\%, and BM at OMR of $40 \%$ were 1.94 , and $0.31 \mathrm{mg} \mathrm{dm}^{-3}$, respectively.

\section{Conclusion}

All macro and micronutrient contents in the millet leaves, and biometric parameters of the millet panicle were affected by the organic matter sources, organic matter rates, and the interaction between them.

Plants grown in soils with poultry litter, and swine manure had the highest macronutrient contents. The leaf tissue of millet plants grown in soils with sewage sludge had the highest micronutrient contents. Macronutrient and micronutrient contents, and biometric parameters of the millet panicles were better when the millet plants were grown in soils with an organic matter rate of $20 \%$.

\section{References}

Alcântara, F. A., \& Madeira, N. R. (2008). Manejo do solo no sistema de produção orgânico de hortaliças (pp. 1-12). Brasília: Embrapa.

Araújo, F. F., Tiritan, C. S., Pereira, H. M., \& Caetano Júnior, O. (2008). Desenvolvimento do milho e fertilidade do solo após aplicação de lodo de curtume e fosforita. Revista Brasileira de Engenharia Agrícola e Ambiental, 12(5), 507-511. https://doi.org/10.1590/S1415-43662008000500011

Bouhafa, K., Moughli, L., Bouabid, R., \& Douaik, A. (2018). Dynamics of macronutrients in olive leaves. Journal of Plant Nutrition, 41(8), 956-968. https://doi.org/10.1080/01904167.2018.1431664

Crusciol, C. A. C., Mateus, G. P., Pariz, C. M., Borghi, E., Costa, C., \& Silveira, J. P. F. (2011). Nutrição e produtividade de híbridos de sorgo granífero de ciclos contrastantes consorciados com capim-marandu. Pesquisa agropecuária brasileira, 46(10), 1234-1240. https://doi.org/10.1590/S0100-204X2011001000017

Embrapa (Empresa Brasileira de Pesquisa Agropecuária). (2013). Sistema brasileiro de classificação de solos (3rd ed., pp. 1-353). Brasília: Centro Nacional de Pesquisa de Solos, Embrapa.

Ferreira, D. F. (2011). Sisvar: A computer statistical analysis system. Ciência e Agrotecnologia, 35(6), 1039-1042. https://doi.org/10.1590/S1413-70542011000600001

Fontaneli, R. S., Fontaneli, R. S., \& Santos, H. P. (2012). Gramíneas forrageiras anuais de verão. In R. S. Fontaneli, H. P. Santos, \& R. S. Fontaneli (Eds.), Forrageiras para Integração Lavoura-Pecuária-Floresta na Região Sul-Brasileira (2nd ed., pp. 1-544). Brasília: Embrapa.

Galvão, S. R. S., Salcedo, I. H., \& Oliveira, F. F. (2008). Acumulação de nutrientes em solos arenosos adubados com esterco bovino. Pesquisa Agropecuária Brasileira, 43(1), 99-105. https://doi.org/10.1590/S0100-204X 2008000100013

Koukoulakis, P. C., Simonis, A. D., \& Gertsis, A. (2000). The organic matter in soils. The problem of Greek soils. Stamoulis Publications, Athens.

Koukoulakis, P., Chatzissavvidis, C., Papadopoulos, A., \& Pontikis, D. (2013). Interactions between leaf macronutrients, micronutrients and soil properties in pistachio (Pistacia vera L.) orchards. Acta Botanica Croatica, 72(2), 295-310. https://doi.org/10.2478/v10184-012-0021-9

Marschner, H. (1995). Mineral Nutrition of Higher Plants (2nd ed., pp. 1-889). Harcourt Brace and Co., London.

Miljković, I., \& Vrsaljko, A. (2009). Genetic specificity of mineral nutrition apple cultivars in orchard Borinci. Pomologia Croatica, 15(2), 3-14.

Milošević, T., \& Milošević, N. (2015). Apple fruit quality, yield and leaf macronutrients content as affected by fertilizer treatment. Journal of Soil Science and Plant Nutrition, 15(1), 76-83.

Miyazawa, M., Pavan, M. A., Muraoka, T., Carmo, C. A. F. S., \& Melo, W. J. (2009.). Análise química de tecido vegetal. In F. C. Silva (Ed.), Manual de análises químicas de solos, plantas e fertilizantes (2nd ed., pp. 191-233). Brasília: Embrapa Informação Tecnológica.

Morais, W. A. (2016). Diferentes tipos de adubações orgânicas na cultura do milheto (pp. 1-54, Tese (Doutorado), IFGoiano, Campus Rio Verde, GO). 
Nachtigall, G. R., \& Dechen, A. R. (2006). Seasonality of nutrients in leaves and fruits of apple trees. Scientia Agricola, 63, 493-501. http://doi.org/10.1590/S0103-90162006000500012

Nagy, P. T., \& Holb, I. J. (2006). Study on the macronutrient content of apple leaves in an organic apple orchard. Journal of Central European Agriculture, 7(2), 329-336.

Novais, R. F., Alvarez, V. V. H., Barros, N. F., Fontes, R. L. F., Cantarutti, R. B., \& Neves, J. C. L. (2007). Fertilidade do Solo (1st ed., pp. 10-1017). Viçosa: Sociedade Brasileira de Ciência do Solo.

Oliveira, P. A. V. (1993). Manual de manejo e utilização dos dejetos de suínos (pp. 1-188). Concórdia: Embrapa-CNPSA.

Pitta, C. S. R., Adami, P. F., Pelissari, A., Assmann, T. S., Franchin, M. F., Cassol, L. C., \& Sartor, L. R. (2012). Year-round poultry litter decomposition and N, P, K and Ca release. Revista Brasileira de Ciência do Solo, 36(3), 1043-1053. https://doi.org/10.1590/S0100-06832012000300034

Santos, A. F., Menezes, R. S. C., Fraga, V. S., \& Pérez-Marin, A. M. (2010). Efeito residual da adubação orgânica sobre a produtividade de milho em sistema agroflorestal. Revista Brasileira Engenharia Agrícola e Ambiental, 14(12), 1267-1272. https://doi.org/10.1590/S1415-43662010001200003

Silva, F. C., Abreu, M. F., Pérez, D. V., Eira, P. A., Abreu, C. A., Van Raij, B., ... Barreto, W. O. (2009). Métodos de análises químicas para avaliação da fertilidade do solo. In F. C. de Silva (Ed.), Manual de análises químicas de solos, plantas e fertilizantes (2nd ed., pp. 107-189). Brasília: Embrapa Informação Tecnológica.

Sobrado, M. (2014). Relationship between Leaf Micro- and Macro-Nutrients in Top Canopy Trees in a Mixed Forest in the Upper Rio Negro in the Amazon Region. American Journal of Plant Sciences, 5(10), 1423-1431. https://doi.org/10.4236/ajps.2014.510157

Teixeira, C. M., Carvalho, G. J., Andrade, M. J. B., \& Furtini Neto, A. E. (2008). Fitomassa, teor e acúmulo de micronutrientes do milheto, feijão-de porco e guandu-anão, em cultivo solteiro e consorciado. Acta Scientiarum. Agronomy, 30(4), 533-538. https://doi.org/10.4025/actasciagron.v30i4.5314

Tisdale, S. L., Nelson, W. L., Beaton, J. D., \& Havlin, J. L. (1993). Soil fertility and fertilizers (pp. 1-754). MacMillan Publishing Co, New York, USA.

\section{Copyrights}

Copyright for this article is retained by the author(s), with first publication rights granted to the journal.

This is an open-access article distributed under the terms and conditions of the Creative Commons Attribution license (http://creativecommons.org/licenses/by/4.0/). 